Ephesians iii. 4, 5, where Paul speaks of the 'mystery of Christ which in other ages was not made known ; . as it is now revealed unto his holy apostles and prophets by the Spirit'. Two classes were entrusted with the revelation of the truth, one of which was the apostles and the other the prophets. We have no record of the testimony of the charismatic prophets, but we have the testimony of the apostles, and they received the truth 'by the Spirit'.

Conscious of this ministry of the Spirit through the apostolic eyewitness, Peter finds no difficulty in placing the same eyewitness testimony on a level with the prophecy of old time, when holy men of God were moved by the Holy Ghost. The Holy Spirit was at work in both Old Testament Scripture and in the true New Testament tradition.

If this conception of the work of the Spirit in the content and transmission of the tradition is correct, and the work He exercises in this respect is limited to the apostolic witness, then any tradition which occurs beyond that limitation can only be the tradition of men. Also, we speak rightly when we say that the Lord spoke to us, when we really mean that the Word of God has come home to us in a certain way. Reliance upon the Scriptures as our final authority is not looking back to a static book, for just as the Spirit was active in speaking through the apostles then, so $\mathrm{He}$ is active in speaking through the apostolic witness now. The Word of God is indeed the Spirit's sword.

Cambridge.

D. J. V. LANE.

\title{
THE NATURE AND PURPOSE OF THE CHARISMATA
}

There have been many divergent evaluations of the nature and purpose of the charismata, or spiritual gifts, which occupy such a prominent place in the life of the early Church. From the various incomplete lists of charismata which are given in the New Testament (Rom. xii. 6-8; 1 Cor. xii. 4-11, 28-30 ; cf. Eph. iv. 7-12) it is evident that their number, variety and diffusion were considerable. Yet each gift had its source in the effectual working of the Holy Spirit and was intended to edify the Body of Christ.

Liberal theologians have been prone to deny the miraculous character of the charismata, and represented them as the natural manifestations of primitive enthusiasm ${ }^{1}$. By the end of the second century this spirit of enthusiasm gave way to 'a more rigid and disciplined Church Order, in which the official tended more and more to supersede the charismatic ministries '.2 The spiritual gifts began to disappear, but, being the product of an abnormal mental state, were liable to emerge under similar conditions in later religious revivals ${ }^{2}$. Certain gifts, such as prophecy and glossolalia, were largely regarded as particular manifestations of familiar phenomena of the Hellenistic age."

By way of contrast, the Roman Catholic theologians have acknowledged the divine origin of the charismata, and have gone on to affirm the permanence of certain gifts in the Church, notably the miracles of healing and other miraculous powers. Support for this general point of view has laid claim to the continuing reality of the powers of miraculous healing and the gift of tongues. In recent years there has been a widespread revival of interest in healing in every branch of the Church and attempts are being made to restore the gift of healing, which was lost (so it is said) as a result of a decline in faith and spirituality, and a growth of asceticism, about the time of the conversion of Constantine in AD $325 .^{\mathrm{s}}$ Similar reasons are often given for the decline of prophecy at a somewhat earlier date, though there have not been wanting those who have said that neither prophecy nor healing have entirely ceased in the history of the Church.

One of the most popular views of the charismata is that advanced by a school of Anglican divines at the beginning of the eighteenth century. This school maintained that the charismata were given for the purpose of founding the Church, and were gradually withdrawn when the Church became strong enough to continue without their assistance. The date for 
the cessation of the charismata is usually placed in the fourth century when Christianity had acquired the support of the civil power." The theory lost none of its popularity despite the fact that as early as $1749 \mathrm{Dr}$. Conyers Middleton pointed out in his famous Free Enquiry that it was contrary to patristic evidence. The silence of the Apostolic Fathers led him to state that in 'an interval of about half a century . . . after the days of the Apostles . . . we find not the least reference to any standing power of working miracles... . but on the contrary the strongest reason to presume that the extraordinary gifts of the Apostolic age were by this time actually withdrawn '.8 He found it impossible to believe that the gifts were withdrawn during the first half of the second century and then restored. Middleton agreed with current Anglican opinion that the charismata were given for the purpose of founding the Church, but held that this had been accomplished in apostolic times.

In 1917, Benjamin Breckinridge Warfield delivered a series of lectures, originally published under the title Counterfeit Miracles (1918), and later as Miracles: Yesterday and Today. (1953). Leaning heavily on Middleton, Warfield sought to reinstate the view of the theologians of the postReformation era that the charismata ceased with the apostolic age. In addition to the argument from silence propounded by Middleton, Warfield examined the writings of the later Fathers and came to the conclusion that there was much greater abundance and precision of evidence, such as it is, for miracles in the fourth and succeeding centuries, than for the preceding ones. The date for the cessation of the charismata suggested by the Anglican school was purely artificial and based on a preconceived theory rather than the facts of history. We are compelled to accept one of two alternatives : either that miraculous powers have never been withdrawn, as the Romanists claim; or that they lasted only as long as the apostolic age. After examining the evidence for the validity of the ecclesiastical miracles Warfield opts for the latter alternative. The charismata were given, according to the New Testament, not directly for the extension of the Church, but for the authentication of the apostles as the messengers of God. The possession of these gifts and the power to confer them on other believers, constituted one of the signs of an apostle. ${ }^{10}$ The gifts ceased gradually with the death of those on whom the apostles had conferred them.

Dr. W. H. Griffith Thomas has regarded the charismata as a testimony to Israel. The gifts are seen to be in operation up to the end of Acts, but not afterwards. 'These facts seem to show that the miraculous gifts recorded in Acts were specifically and solely for Israel; that they were demonstrations of power to vindicate the Messiahship of Jesus of Nazareth, but not intended for permanent exercise in the normal conditions of the Christian Church when Christ had been rejected by Israel ... . Acts iii. 19-21 plainly teaches that if only the Jews had then and there repented, Jesus Christ would have come back according to His own promise, but as they wilfully refused to accept $\mathrm{Him}$, and maintained this refusal on every occasion when the offer was made, the supernatural manifestations of the Holy Spirit came to an end, and the normal graces of the Spirit became naturally more prominent in the Gentile Christian Church and as associated with the Apostle Paul.'11

In the face of this rather bewildering variety of opinion, one may well ask, What is the truth about the nature, purpose and continuance of the charismata? To answer the question it is clearly necessary to give close attention to the teaching of the New Testament in an effort to formulate a distinctly biblical doctrine of the charismata. The subject has long been obscured by hazy theories defended in the smoke of controversy, and there has been surprisingly little thorough examination of biblical evidence. There is need for an accurate definition of terminology, and a careful enquiry into the relation of the charismata to Christ, the Holy Spirit, the Church and its ministry. Investigation will have to be made into many subsidiary problems, such as the nature of the Pentecostal and Corinthian glossolalia, and the relation of the charismata to similar supranormal phenomena mentioned in patristic and Hellenistic literature. This enquiry is now in progress.

Dudley.

WILBERT G. PUTMAN. 


\section{References:}

1. Cf. P. W. Schmiedel, Encyclopaedia Biblica, cols. 4775-6.

2. R. Martin Pope, art. 'Gifts', Hastings' Dictionary of the Apostolic Church, vol. I, p. 451.

3. W. James, Varieties of Religious Experience, pp. 23, 478. M. Barnett, The Living Flame, pp. 129f.

4. See H. A. Guy, New Testament Prophecy, p. 144 (and references). And for glossolalia, see P. Volz, Der Geist Gottes, p. 197, quoted by M. Barnett, The Living Flame, p. 103. Both Guy and Barnett offer valuable criticisms of theories postulating the essential similarity of Christian and non-Christian prophecy and glossolalia.

5. Cf. Leslie D. Weatherhead, Psychology, Religion and Healing, pp. $85 \mathrm{ff}$. J. C. Lambert, art. 'Healing, Gifts of', International Standard Bible Encyclopaedia, vol. II, p. 1350a.

6. Guy, op. cit., pp. 150ff., and Barnett, op. cit., pp. 113ff. give various reasons for the decline of prophetism. C. von Otrelli, art. 'Prophecy', I.S.B.E., vol. IV, p. 2464a, claims that prophecy has never ceased altogether.

7. Cf. Conyers, Middleton, Introductory Discourse, pp. xlvi-xlvii. John Tillotson, Sermon Fol. 3 it. Vol. 3, p. 488. Edit. 1735. Nathaniel Marshall, Epistles of Cyprian, not. b. Henry Dodwell, Dissert. in Iren. 2. para. LV. Daniel Waterland, Treatise on the Importance of the Doctrine of the Trinity, pp. 299, 382-3, 425, 497. John Chapman, Miscell. Tracts., p. 170. William Whiston, Account of the Daemoniacs, p. 65. All the above cited in Middleton, Introductory Discourse, pp. xlvii-li ; and in Warfield, Miracles, pp. 7f. Cf. Wesley, Works, Vol. V, p. 706. Cited by Warfield, Miracles, p. 8, who also refers to later supporters of the theory.

8. Middleton, Free Enquiry, p. 9.

9. Warfield, Miracles, 'The Cessation of the Charismata' (pp. 3-31), passim. Cf. F. J. Foakes-Jackson, History of the Christian Church, p. 241, note 1.

10. Warfield, op. cit., pp. 3, $21 \mathrm{f}$.

11. W. H. Griffith Thomas, The Holy Spirit of God, pp. 48-49.

\section{THE KINGDOM, THE POWER AND THE GLORY}

It is generally accepted that the idea of the kingdom of God was the central theme in the preaching of Jesus. Most scholars would also agree with T. W. Manson that it is 'something through and through spiritual' and 'a personal relation between God and the individual human being', while, of course, implying a community of people who would live together under the rule of God. But concerning the time of the coming of the kingdom there still remains considerable disagreement. It seems that there are grave weaknesses in all the main positions that have come to my notice at least. Thorough-going eschatology has lost much ground and is faced with many passages in the Gospels as we have them, which seem to state quite clearly that the kingdom has arrived (whatever may be the meaning of engiken in Mk. i. 15). If that is what Jesus taught, we have to assume that a disappointed Church managed to adjust itself well enough to the situation to read back into the words of Jesus a more correct interpretation than He had been able to offer. In opposition to that is set realized eschatology. We are greatly indebted to Prof. Dodd and others for the important light that they have shed upon the subject in this direction, but there are places in such a work as The Parables of the Kingdom where his exegesis seems to be strained further than is legitimate. There are sayings in all strands of the synoptic tradition which are hard to apply to anything but the Parousia (e.g. Mk. viii. 38 ; Mt. xxiv. 27 ; Lk. xvii. 24 from $Q$; Mt. xix. 28 from $M$; Lk. xxi. 31 from $L$.) There are too many references to be written off as being due to misunderstanding by the early Church. If they were so radically wrong on so vital a matter, the reliability of the 